\title{
Transition from Secondary School to Medical School: The Role of Self-Study and Self-Regulated Learning Skills in Freshman Burnout
}

\author{
Transição do Ensino Secundário para a Escola Médica: \\ O Papel do Tempo de Estudo e das Competências de \\ Autorregulação da Aprendizagem no Burnout Académico
}

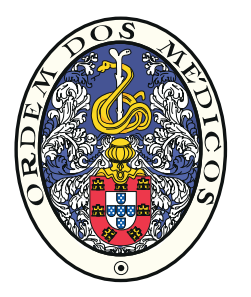

\author{
Joselina BARBOSA $\triangle^{1}$, Álvaro SILVA ${ }^{2}$, Maria Amélia FERREIRA ${ }^{1}$, Milton SEVERO ${ }^{1}$ \\ Acta Med Port 2016 Dec;29(12):803-808 - http://dx.doi.org/10.20344/amp.8350
}

\section{ABSTRACT}

Introduction: The transition from secondary to higher education is a challenging and demanding period for medical students. The ability to manage study time effectively and to be a self-regulated learner is essential to cope with the exponential growth of knowledge in medical education. Thus, the purpose of our study was to measure self-regulated learning skills and self-study across secondaryhigher education transition and to explore its effect on academic burnout in the first year of medical school.

Material and Methods: We collected data from 102 (43\%) freshman medical students on self-regulated learning, academic achievement, and hours of self-study/week relative to last year of secondary school (at the beginning of academic year) and the first year of medical school (at the end of academic year). Burnout data was collected at the end of academic year.

Results: Among the 102 participants, $12 \%$ were at risk of burnout. Self-directedness at secondary school and higher education, and strategies for learning and assessment at higher education were protective factors against academic burnout. However, secondary selfdirectedness has an indirect effect on academic burnout mediated by self-directedness in the first year of medical school. In addition, self-study during class period was a risk factor for burnout.

Conclusion: Our results support the premise that students experience mental health problems from an early stage at medical school. Empowering medical students to develop strategies for learning assessment and self-direction will help them manage their learning and, consequently, promote their well-being. Finally, we found that it is not academic performance that influences burnout but the time dedicated to study.

Keywords: Education, Medical, Undergraduate; Educational Status; Learning; Motivation; Portugal; Self-Control.

\section{RESUMO}

Introdução: A transição do ensino secundário para o ensino superior é um desafio para o estudante de medicina. Gerir o tempo de estudo e promover as competências de autorregulação da aprendizagem torna-se fundamental para lidar com o exponencial do conhecimento na educação médica. Este estudo pretende avaliar as competências de autorregulação da aprendizagem e o tempo de estudo na transição do secundário para o ensino superior, e explorar o seu efeito no burnout académico no primeiro ano do curso de medicina. Material e Métodos: Foram recolhidos dados de 102 (43\%) estudantes do primeiro ano do curso de medicina acerca das competências de autorregulação da aprendizagem, desempenho académico e tempo de estudo/semana no início do ano letivo (relativos ao último ano do secundário) e no final do mesmo (relativos ao primeiro ano do curso) - nesta fase foi também avaliado o burnout.

Resultados: A exposição ao burnout ocorreu em $12 \%$ dos estudantes. A aprendizagem auto-direcionada no ensino secundário e superior e adoção de estratégias de aprendizagem e de avaliação no ensino superior apresentaram efeito protetor de burnout. Contudo, a aprendizagem auto-direcionada no ensino secundário teve efeito indireto no burnout académico através da aprendizagem autodirecionada no ensino superior.

Conclusão: Os estudantes de medicina experienciam problemas de saúde no primeiro ano do curso. Capacitá-los a desenvolver estratégias de aprendizagem e de avaliação e direcionarem autonomamente as suas aprendizagens terá impacto no seu bem-estar. Não é o desempenho académico que influencia o burnout mas o tempo de estudo.

Palavras-chave: Aprendizagem; Autocontrolo; Educação Médica Pré-Graduada; Escolaridade; Estudantes de Medicina/psicologia; Motivação; Portugal.

\section{INTRODUCTION}

Student burnout is a psychological syndrome characterized by emotional exhaustion resulting from academic demands, having a cynical attitude toward studies, and feelings of incompetence when studying. ${ }^{1}$ In recent years, there has been concerns that medical students may be at increased risk of such psychological problems due to stress caused by the demands of medical school and concerns of failing, ${ }^{2-4}$ which tend to extend to medical practice..$^{5-7}$

Previous research has suggested that burnout occurs in medical students at a significantly higher rate compared with undergraduate students in other university courses. ${ }^{8,9}$ In addition to personal characteristics and life events, the learning environment appears to critically influence student burnout. $4,10,11$ Moreover, only the learning context is under the teachers' control; faculty staff should take steps to improve the learning environment at their respective

\footnotetext{
1. Department of Public Health and Forensic Sciences and Medical Education. Faculdade de Medicina. Universidade do Porto. Porto. Portugal.

2. Department of Pre-Graduate Education. Instituto de Ciências Biomédicas Abel Salazar. Universidade do Porto. Porto. Portugal.

$\triangle$ Autor correspondente: Joselina Barbosa. joselina@med.up.pt

Recebido: 29 de outubro de 2016 - Aceite: 27 de novembro de 2016 | Copyright @ Ordem dos Médicos 2016
} 
institutions. ${ }^{12}$ Against this background, it is important to understand how the learning environment affects medical student burnout. Although there exists various sources of stress in the preclinical and clinical years, student burnout begins in the freshman year of university. ${ }^{13,14}$ Most studies that have focused on the clinical years attribute sources of stress to academic pressure in the first year of training, and to exposure to death and suffering. ${ }^{15}$ From the preclinical years through the clinical years, the level of support provided by faculty, and the workload and facts to be learned within a limited time were found to be associated with student burnout. ${ }^{16,17}$ Given that promotion of involvement in the first year of medical school is an essential method of establishing bases for success in subsequent years, ${ }^{18}$ problems with medical students' mental health should be addressed from the very start of the degree program. In this study, we focus on the transition from secondary to medical school. Going to university is a challenge for most students, and medicine is considered a difficult and demanding program. Learning at university is less directed, and it is expected that students engage with and take responsibility for their own learning, complete tasks independently, despite conditions of increased stress and reduced confidence..$^{19,20}$ Being able to manage study time effectively and be a selfregulated learner is essential to succeed in the first year and to cope with the exponential growth of knowledge in medical education. ${ }^{18}$ This has led to an emphasis on selfregulated learning, which includes the ability to effectively plan and formulate educational goals, and plan how to reach them, using strategies for learning assessment, scheduling and managing study time and resources; that is, students have to be "metacognitively, motivationally, and behaviorally active participants of their own learning process". ${ }^{21-24}$ As described above, learning and retention of self-regulated learning skills can not only help students succeed but also to develop and foster healthy behaviors in complex environments. ${ }^{25}$

Given that prior knowledge and skill influence how students process and integrate incoming information, ${ }^{26}$ we hypothesized that learners with prior high self-regulated learning skills have an easier transition into higher education compared with other learners.

In recognition that transition from secondary to higher education is a distinct period for medical students, the purpose of the present study was to evaluate changes in the use of self-regulated learning skills and time for study from secondary to higher education and if these affect academic burnout in the first year of medical school.

\section{MATERIAL AND METHODS \\ Participants and procedures}

First-year medical students from the Faculty of Medicine of the University of Porto were enrolled in this study. We collected data from first-year medical students on selfregulated learning skills, academic achievement, and academic study at two time points. The first survey was conducted just after the beginning of classes (T0, September 2014, Appendix 1) [http://www.actamedicaportuguesa.com/ revista/index.php/amp/article/download/8350/4851]. The second survey was conducted at the end of academic year t (T1, September 2015, Appendix 2) [http://www. actamedicaportuguesa.com/revista/index.php/amp/article/ download/8350/4852]. Burnout data was collected at T1.

At T0, questionnaires were distributed and collected at the end of the lecture from the students who had agreed to participate in the study. At T1, questionnaires were distributed and collected by a second-year student representative. During the administration, students were assured verbally and in writing that their responses would be confidential. Participation was voluntary. In total, 120 first-year medical students completed the survey; however, only 102 (43\% of enrolled students) completed the follow-up assessment. There was no statistically significant difference between participants based on these variables at both T0 and T1 (data not shown).
T0

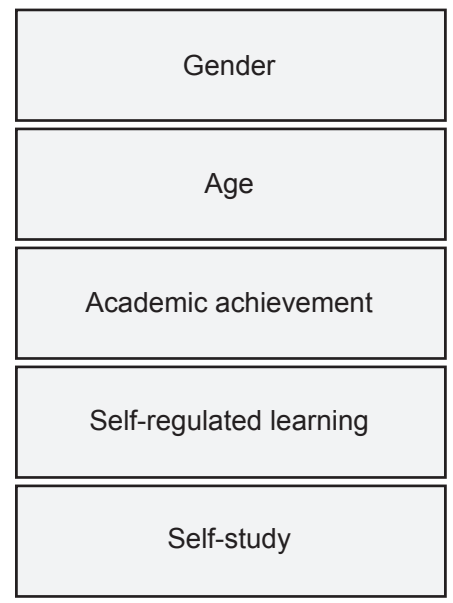

Freshman's burnout

T1

\section{Outcome}

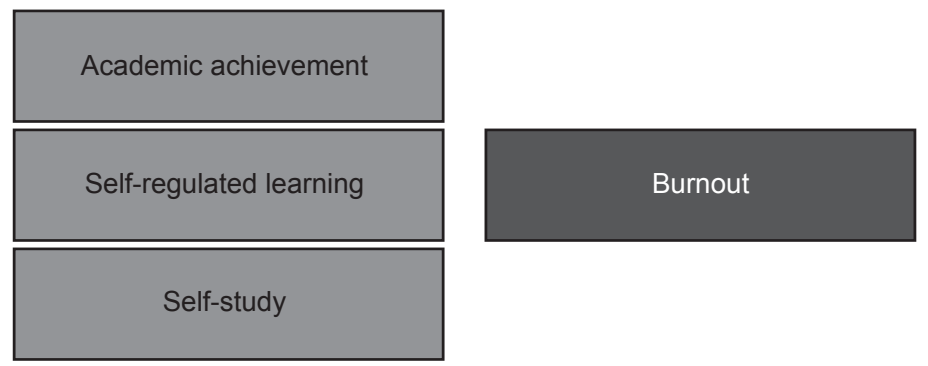

Figure 1 - Conceptual model: predictors of medical student burnout across secondary-higher education transition 
The analytical framework was built into the conceptual model displayed in Fig. 1.

\section{Measures}

Covariates

Demographic information collected included age and gender.

At T0, academic achievement was calculated as follows: $50 \%$ of the final average grade in secondary school and $50 \%$ of the grades in biology and geology, physics and chemistry and mathematics in the national exams, evenly distributed throughout the exams. At T1, academic achievement was the first-year average grade.

\section{Self-study hours}

Self-study was assessed using a retrospective selfstudy frequency questionnaire that included two questions: 1) 'How often did you study outside the classroom for learning purposes, (whether it was for class assignments, group work, or studying for an assessment)?' and 2) 'On the days that you studied, how many hours did you study on average per day?' For the first question, students had a Likert scale of response options to choose from: never, once, or less than once a month; 2 to 3 times per month; once a week; twice a week; 3 to 4 times per week; 5 times per week; and 6 to 7 times per week. These questions were asked for the class period and for the assessment period. ${ }^{27}$ To calculate the amount of self-study per week, the selected frequency category was converted to mean times/week and multiplied by the number of self-study hours. For example, a response of '2-3 times/month' was converted to 0.625 times/week (2.5 months divided by 4 weeks).

\section{Self-regulated learning skills}

Self-regulated learning skills were assessed using the Self-regulated Learning Perception Scale (SRLPS), ${ }^{24}$ which has been validated in medical students. This tool includes 41 items that measure the following dimensions: motivation and action to learning (seven items), planning and goal setting (eight items), strategies for learning and assessment (19 items), and lack of self-directedness (seven items). Items are answered using a five-point scale ranging from 'strongly disagree' to 'strongly agree'. Lack of self-directedness has an inverse score and was therefore reversed. For all dimensions, higher scores reflect higher level of self-regulated learning skills. In order to be comparable, all dimensions were converted to a scale from 0 to 100. The internal consistency of SRLPS was 0.921 and 0.939 at $\mathrm{T} 0$ and $\mathrm{T} 1$, respectively.

\section{Burnout}

Burnout was measured using the Portuguese version of the Maslach Burnout Inventory - Student Survey (MBISS). ${ }^{28}$ This 15 -item questionnaire was formulated to assess academic burnout and includes three subscales evaluating: emotional exhaustion, (six items), cynicism (four items), and academic efficacy (five items). All items were scored on a seven-point frequency rating scale from 0 (never) to 6 (always). The items concern how burdensome students feel university studies to be, and how often and how intensely they have experienced certain conditions. ${ }^{29}$ According to Maslach and Jackson, individuals presenting with emotional exhaustion and cynicism values above the $66^{\text {th }}$ percentile and professional efficacy results below the $33^{\text {rd }}$ percentile of the sample they are considered to have burnout syndrome. ${ }^{1}$ We dichotomized burnout into an outcome variable 'without burnout' and 'with burnout'. Also, finally scores of each dimension of burnout were obtained. Higher scores reflected a higher level of emotional exhaustion and cynicism. Academic efficacy has an inverse score - a higher score indicated better self-perception of the student's academic efficacy. In order to be comparable, all dimensions were converted to a scale from 0 to 100 . The internal consistency of burnout was 0.909 .

\section{Data analysis}

Data was summarized as means with standard deviation (SD), or medians with $25^{\text {th }}$ percentile ( $p 25$ ) and $75^{\text {th }}$ percentile (p75). We used the Wilcoxon rank-sum test and t-test for paired data. A multilevel logistic regression was carried out to identify relationships between self-regulated learners and self-study with respect to burnout in the first year of the medical program. A model was constructed with burnout as the dependent variable: Model 1a, assessing the crude association between demographic and baseline variables and burnout; Model 1b, assessing the association between all demographic and baseline variables and burnout using a backward logistic regression elimination method and setting the alpha value at $p<0.10$; Model $2 a$, assessing the crude association between follow-up variables and burnout; Model $2 \mathrm{~b}$, assessing the association between follow-up variables and burnout using a backward logistic regression elimination method setting the alpha value at $p<$ 0.10 ; Model 3 , independent variables yielding a significant association in Model $1 \mathrm{~b}$ and Model $2 \mathrm{~b}$, were used to build the final model. We calculated the log-likelihood $p$ value to assess statistically significant improvements in the final model.

\section{RESULTS}

\section{Participants' characteristics}

Participants' characteristics at T0 and at T1 are described in Table 1. The average student in the sample was 18.1 years $(S D=1.4)$ years and $63.7 \%$ were girls Statistically significant differences were found from T0 to T1 on academic achievement, self-study during class period, self-study during the assessment period, motivation and action to learn, and strategies for learning and assessment. All of the significant changes were in a negative direction, indicating a decrease in self-regulated skills and academic achievement and an increase in self-study, both during classes and the assessment period. Planning and goal setting as well as self-directedness showed no differences from T0 to T1. 
Table 1 - Participant's characteristics at baseline and at follow-up

\begin{tabular}{|c|c|c|c|}
\hline & T0 & T1 & $p$ value \\
\hline Age at baseline, mean (SD) & $18.1(1.4)$ & - & - \\
\hline Gender, N (\%) & & - & \\
\hline Girls & $65(63.7)$ & & \\
\hline Boys & $37(36.6)$ & & \\
\hline Academic achievement, mean (SD) & $18.0(0.8)$ & $13.3(1.5)$ & $<0.001$ \\
\hline \multicolumn{4}{|l|}{ Self-study, median ( $225 ; \mathrm{p} 75)$} \\
\hline Self-study (class period), hours per week & $7.0(4.0 ; 13.0)$ & $12.4(6.0 ; 20.0)$ & $<0.001$ \\
\hline Self-study (assessment period), hours per week & $32.5(21.0 ; 45.5)$ & $65.0(52.0 ; 78.0)$ & $<0.001$ \\
\hline \multicolumn{4}{|l|}{ Self-regulated learning skills, median $(p 25 ; p 75)^{*}$} \\
\hline Motivation and action to learning & $75.0(71.4 ; 82.1)$ & $75.0(64.3 ; 75.0)$ & $<0.001$ \\
\hline Planning and goal setting & $75.0(68.8 ; 81.3)$ & $75.0(62.5 ; 81.3)$ & 0.174 \\
\hline Strategies for learning and assessment & $72.4(67.1 ; 80.3)$ & $68.4(63.2 ; 73.7)$ & $<0.001$ \\
\hline Self-directedness & $67.9(57.1 ; 75.0)$ & $67.9(53.6 ; 75.0)$ & 0.465 \\
\hline
\end{tabular}

* Scale from 0 to 100

Table 2 - Predictors of burnout among first year medical students

\begin{tabular}{|c|c|c|c|c|}
\hline & \multicolumn{2}{|c|}{ TO } & \multicolumn{2}{|c|}{ T1 } \\
\hline & Model 1a & Model $1 b^{*}$ & Model 2a & Model $2 b^{*}$ \\
\hline & OR $(95 \% \mathrm{CI})$ & OR $(95 \% \mathrm{CI})$ & OR $(95 \% \mathrm{Cl})$ & OR $(95 \% \mathrm{Cl})$ \\
\hline Gender (female) & $0.72(0.21 ; 2.48)$ & - & & - \\
\hline Age & $1.12(0.70 ; 1.81)$ & - & & - \\
\hline Academic achievement & $1.95(0.72 ; 5.31)$ & - & $0.83(0.53 ; 1.30)$ & - \\
\hline \multicolumn{5}{|l|}{ Self-study } \\
\hline Self-study (class period), hours per week & $1.00(0.95 ; 1.05)$ & - & $1.02(0.98 ; 1.07)$ & $1.09(1.01 ; 1.17)$ \\
\hline Self-study (assessment period), hours per week & $1.01(0.98 ; 1.05)$ & - & $1.03(0.99 ; 1.07)$ & - \\
\hline \multicolumn{5}{|l|}{ Self-regulated skills } \\
\hline Motivation and action to learning & $0.97(0.91 ; 1.04)$ & - & $0.91(0.85 ; 0.97)$ & - \\
\hline Planning and goal setting & $0.97(0.92 ; 1.02)$ & - & $0.93(0.89 ; 0.97)$ & - \\
\hline Strategies for learning assessment & $0.93(0.86 ; 1.01)$ & - & $0.84(0.78 ; 0.92)$ & $0.85(0.76 ; 0.94)$ \\
\hline Self-directedness & $0.95(0.92 ; 0.99)$ & $0.95(0.92 ; 0.99)$ & $0.93(0.89 ; 0.97)$ & $0.94(0.89 ; 1.00)$ \\
\hline
\end{tabular}

*Backward stepwise selection

Bold font implies statistically significant results assuming a $5 \%$ significance threshold

Table 3 - Predictors of burnout among first year medical students: results from multilevel logistic regression model

\begin{tabular}{lcc}
\hline & $\begin{array}{c}\text { Model } \\
\text { OR }(95 \mathrm{Cl} \%)\end{array}$ & $p$ value \\
\hline Baseline & & 0.745 \\
$\quad$ Self-directedness & $1.01(0.95 ; 1.08)$ & 0.011 \\
Follow-up & & $<0.001$ \\
Self-study (class period), Mean hours per week (SD) & $1.10(1.02 ; 1.18)$ & 0.045 \\
Strategies for learning and assessment & $0.85(0.76 ; 0.94)$ & $0.94(0.88 ; 1.00)$ \\
Self-directedness & & 0.045 \\
\hline
\end{tabular}

\section{Student burnout in the first year of medical school}

According to the $66^{\text {th }}$ percentile of emotional exhaustion and cynicism and the $33^{\text {rd }}$ percentile of efficacy exhaustion, 12 participants (12\% of the total sample) were at risk of burnout. The median scores for emotional exhaustion, cynicism and academic efficacy among the participants were 53.3 (p25 - p75: 36.7 - 73.3), 25.0 (p25 - p75: 12.5 -
37.5) and 63.9 (p25 - p75: 52.8 - 750.), respectively.

At T0, considering the age, gender, and academic achievement as covariates, the logistic regression model revealed that only self-directedness (OR $=0.95 ; \mathrm{Cl} 95 \%$ : $0.92-0.99$ ) was significantly associated with burnout. At $\mathrm{T} 1$, high burnout levels were significantly associated with self-study during class period $(\mathrm{OR}=1.09$; $\mathrm{Cl} 95 \%$ : $1.01-$ 
1.17), strategies for learning and assessment $(\mathrm{OR}=0.85$ $\mathrm{Cl} 95 \%: 0.76-0.94)$, and self-directedness (OR $=0.94 ; \mathrm{Cl}$ 95\%: $0.89-1.00$ ) (Table 2).

After adjusting for baseline and follow-up variables, high burnout levels were significantly associated with selfstudy during class period (OR = 1.10; Cl 95\%: $1.02-1.18)$, strategies for learning and assessment (OR = 0.85; $\mathrm{Cl} 95 \%$ : $0.76-0.94$ ) and self-directedness (OR $=0.94 ; \mathrm{CI} 95 \%: 0.88$ $-1.00)$ at higher education. It seems that self-directedness in secondary school has an indirect effect on academic burnout at medical school mediated by self-directedness at higher education (Table 3).

\section{DISCUSSION}

In this study, we assessed the effect of self-regulated learning skills and self-study throughout the secondaryhigher education transition and explored its impact on academic burnout in the first year of medical school.

We found that $12 \%$ of medical students experienced burnout; thus, a small percentage of medical students' experience burnout in their first year of medical course. Several attempts have been made to evaluate the prevalence of student burnout. An early report estimated the prevalence as $10 \%$ to $45 \%$ of all students. ${ }^{30}$ Regarding the first year of medical school, Santen et al reported a burnout prevalence of $21 \%{ }^{31}$ and Almeida et al reported a prevalence of $14.9 \% .{ }^{32}$ Additionally, according to other studies, burnout increases across curricular years. ${ }^{10,33}$

First-year medical students in this study had moderate emotional exhaustion, no cynicism, and moderate academic efficacy. This indicates that, at the end of the first year, they are still have positive expectation toward their studies in general, and thus feel engaged in learning, although they may experience some academic fatigue.

The most relevant finding of our study was that self-regulated learning skills might be important for the prevention of burnout. It has previously been observed that more highly self-regulated learners are more successful at school and experience less stress, ${ }^{34}$ because these skills allow them to manage their emotions, thoughts, and actions in order to cope with and adapt to the challenges of higher education. ${ }^{35}$ In our study, it was found that selfdirectedness at secondary and higher education, and strategies for learning and assessment at higher education were protective against academic burnout. However, the effect of secondary self-directedness is mediated by selfdirectedness in the first year of medical school, i.e. selfdirected students at secondary are more likely to be selfdirected in higher education which in turn leads them to lower academic burnout. This implies that students who adopt such strategies for attaining goals and exercise both control and personal autonomy are more likely feel less burnt out by the demands of medical school. Nonetheless, in our sample, these self-regulated learning skills did not increase from secondary to higher education, and scores for learning and assessment strategies decreased over time.
These differences may be explained by students' attitudinal and behavioral changes from secondary school to the first year of higher education. They may feel unprepared for this shift away from lectures towards a more self-directed approach, which requires considerable self-regulation. Secondary education is largely teacher-centered; however, in higher education, students need to self-regulate. ${ }^{36}$ Given that self-regulation towards learning is not considered a personality trait and students are expected to become better self-regulated learners in medical school, ${ }^{23}$ the first responsibility of teachers is to develop and optimize these competences in students.

On the other hand, our study showed no association between motivation and action to learning or planning and goal setting and academic burnout. Since self-regulated learning skills have been highlighted as predictive factors of well-being and academic achievement, ${ }^{25,37}$ we believe that these skills are more related to academic performance rather than enhancing academic well-being.

Although, self-study during both classes and the assessment period increased, and academic achievement decreased from secondary to higher education, the results of this study indicate that only self-study during class period in higher education appear to be directly related to burnout. This means that it is the way students engage with studies and not academic performance that influences burnout. It is not surprising that self-study increased from secondary to higher education given the demands of medical school. The teaching approach at higher education highlights the active role of students in learning, and as a consequence, depends on students' study time. Other research has demonstrated that first year students feel more overwhelmed at midterms due to the initial demands and volume of course materials than at their final exams. ${ }^{38}$ This further highlights the importance of introducing students to strategies for learning, assessment, and self-directedness to prevent overloading.

Finally, it is important to note that this study was conducted in a single educational institution; thus, the findings may not be generalizable.

\section{CONCLUSION}

Our results support the premise that students experience health problems during the first year of medical school. This study showed that self-regulated learning skills and self-study are related to burnout. According to our results, strategies for learning and assessment and self-directedness were protective factors, while self-study when classes were in session was a risk factor. Thus, empowering medical students to develop strategies for learning assessment and self-direction from and early stage will affect how they manage their learning environment and promote medical students' well-being. This study extends existing research by providing evidence that students' selfdirectedness contributes to changes in their mental health one year later. 


\section{PROTECTION OF HUMANS AND ANIMALS}

The authors declare that the procedures were followed according to the regulations established by the Clinical Research and Ethics Committee and to the Helsinki Declaration of the World Medical Association.

\section{DATA CONFIDENTIALITY}

The authors declare having followed the protocols in use

\section{REFERENCES}

1. Maslach C, Jackson SE. MBI: Maslach Burnout Inventory; manual research edition. Palo Alto: University of California; 1986.

2. Aherne D, Farrant K, Hickey L, Hickey E, McGrath L, McGrath D. Mindfulness based stress reduction for medical students: optimising student satisfaction and engagement. BMC Med Educ. 2016;16:209.

3. Dyrbye LN, Thomas MR, Shanafelt TD. Systematic review of depression, anxiety, and other indicators of psychological distress among US and Canadian medical students. Acad Med. 2006;81:354-73.

4. Dyrbye LN, Thomas MR, Huntington JL, Lawson KL, Novotny PJ, Sloan $\mathrm{JA}$, et al. Personal life events and medical student burnout: a multicenter study. Acad Med. 2006;81:374-84.

5. Arigoni F, Bovier PA, Mermillod B, Waltz P, Sappino A-P. Prevalence of burnout among Swiss cancer clinicians, paediatricians and general practitioners: who are most at risk? Support Care Cancer. 2009;17:7581.

6. Willcock SM, Daly MG, Tennant CC, Allard BJ. Burnout and psychiatric morbidity in new medical graduates. Med J Aust. 2004;181:357-60.

7. Maroco J, Maroco AL, Leite E, Bastos C, Vazão MJ, Campos J. Burnou in portuguese healthcare professionals: an analysis at the national nevel. Acta Med Port. 2016;29:24-30.

8. Dyrbye LN, West CP, Satele D, Boone S, Tan L, Sloan J, et al. Burnout among US medical students, residents, and early career physicians relative to the general US population. Acad Med. 2014;89:443-51.

9. Bíró É, Balajti I, Ádány R, Kósa K. Determinants of mental well-being in medical students. Soc Psychiatry Psychiatr Epidemiol. 2010;45:253-8.

10. Santen SA, Holt DB, Kemp JD, Hemphill RR. Burnout in medical students: examining the prevalence and associated factors. South Med J. 2010;103:758-63.

11. Dyrbye LN, Thomas MR, Harper W, Massie FS Jr, Power DV, Eacke $A$, et al. The learning environment and medical student burnout: a multicentre study. Med Educ. 2009;43:274-82.

12. Cope C, Staehr L. Improving students' learning approaches through intervention in an information systems learning environment. Stud High Educ. 2005;30:181-97.

13. Mazurkiewicz R, Korenstein D, Fallar R, Ripp J. The prevalence and correlations of medical student burnout in the pre-clinical years: a crosssectional study. Psychol Health Med. 2012;17:188-95

14. Romani M, Ashkar K. Burnout among physicians. Libyan J Med. 2014;9:23556.

15. MacLeod RD, Parkin C, Pullon S, Robertson G. Early clinical exposure to people who are dying: learning to care at the end of life. Med Educ. 2003;37:51-8

16. Stewart SM, Betson C, Lam T, Marshall I, Lee P, Wong C. Predicting stress in first year medical students: a longitudinal study. Med Educ. 1997;31:163-8.

17. Fares J, Saadeddin Z, Al Tabosh H, Aridi H, El Mouhayyar C, Koleilat MK, et al. Extracurricular activities associated with stress and burnout in preclinical medical students. J Epidemiol Glob Health. 2016;6:177-85.

18. Krause KL, Coates $H$. Students' engagement in first-year university. Assess Eval High Educ. 2008;33:493-505.

19. Torenbeek M, Jansen E, Suhre C. Predicting undergraduates' academic at their working center regarding patients' data publication.

\section{CONFLICTS OF INTEREST}

The authors declare that there are no conflicts of interest.

\section{FUNDING SOURCES}

No subsidies or grants contributed to this work.

achievement: the role of the curriculum, time investment and selfregulated learning. Stud High Educ. 2013;38:1393-406.

20. Barrows HS. Problem-based, self-directed learning. JAMA. 1983;250:3077-80.

21. Zimmerman BJ. A social cognitive view of self-regulated academic learning. J Educ Psychol. 1989;81:329-339.

22. Schunk DH, Zimmerman BJ. An essential dimension of self-regulated learning. Motivation and self-regulated learning: Theory, research, and applications. London: Taylor and Francis; 2008.

23. Zimmerman BJ. Becoming a self-regulated learner: an overview. Theory Pract. 2002;41:64-70

24. Turan S, Demirel Ö, Sayek I. Metacognitive awareness and selfregulated learning skills of medical students in different medical curricula. Med Teach. 2009;31:e477-83.

25. Zimmerman BJ, Boekaerts M, Pintrich P, Zeidner M. A social cognitive perspective. Handb Self-Regulation. 2000;13.

26. Marton F, Hounsell D, Entwistle NJ. The experience of learning implications for teaching and studying in higher education. Edinburgh: Scottish Academic Press; 1997.

27. Kerdijk W, Cohen-Schotanus J, Mulder B, Muntinghe FL, Tio RA Cumulative versus end-of-course assessment: effects on self-study time and test performance. Med Educ. 2015;49:709-16.

28. Maroco J, Tecedeiro M. Maslach burnout inventory-student survey portuguese version. Psicol Saude Doenças. 2009;10:227-35.

29. Hazag A, Major J, Ádám S. Assessment of burnout among students. Validation of the Hungarian version of the Maslach Burnout InventoryStudent Version (MBI-SS). Mentálhig. pszichoszomat. 2010;11:151-68.

30. Dyrbye LN, Thomas MR, Massie FS, Power DV, Eacker A, Harper W, et al. Burnout and suicidal ideation among US medical students. Ann Intern Med. 2008;149:334-41.

31. Schaufeli WB, Leiter MP. Maslach burnout inventory-general survey The Maslach burnout inventory-test manual. Palo Alto: Consulting Psychologists Press; 1996.

32. Almeida GC, Souza HR, Almeida PC, Almeida BC, Almeida GH The prevalence of burnout syndrome in medical students. Arch Clin Psychiatry. 2016;43:6-10.

33. Galán F, Sanmartín A, Polo J, Giner L. Burnout risk in medical students in Spain using the Maslach Burnout Inventory-Student Survey. Int Arch Occup Environ Health. 2011:84:453-9.

34. Baumeister RF, Vohs KD. Self-regulation, ego depletion, and motivation. Soc Personal Psychol Compass. 2007;1:115-28.

35. Duru E, Duru S, Balkis M. Analysis of relationships among burnout, academic achievement, and self-regulation. ESTP. 2014;14:1274-84.

36. Demirören M, Turan S, Öztuna D. Medical students' self-efficacy in problem-based learning and its relationship with self-regulated learning. Med Educ Online. 2016;21.

37. Zimmerman BJ. Enhancing student academic and health functioning: A self-regulatory perspective. Sch Psychol Q. 1996;11:47.

38. Ball S, Bax A. Self-care in medical education: effectiveness of healthhabits interventions for first-year medical students. Acad Med. 2002;77:911-7. 